\title{
German in Wisconsin: Language Change and Loss
}

Peter Wagener

\section{Zusammenfassung}

Der Aufsatz nähert sich der Frage, wie Sprachwandel beobachtet und beschrieben werden kann, auf empirischen Wege: Es werden Sprachbiographien von deutschstämmigen Amerikaner(inne)n aus Wisconsin nachgezeichnet. Diese Fallstudien von denen hier zwei etwas näher beleuchtet werden - lassen ganz unterschiedliche Entwicklungen in der Lebenszeit eines Sprechers erkennbar werden. Der Beibehaltung und behutsamen Wandlung im Sprachgebrauch einer schweizerdeutschen Sprecherin steht der beinahe komplette Verlust der deutschen Sprachkompetenz einer Niederdeutsch-Sprecherin gegenüber.

Für die Rekonstruktion dieser Wandlungsprozesse in realer Zeit wird die Methode des Re-Recordings präsentiert - der erneuten Aufnahme von Sprechern, die in früheren Tonaufnahme-Aktionen in Wisconsin bereits einmal erfasst wurden (hier: 1968 und 2001). Erste Ergebnisse der zu Grunde liegenden linguistischen Analysen werden in Tabellen dargestellt.

\section{Problems in observing and describing language change}

The determination of the means and results of language change is one of the foremost pursuits of linguistic research. For a long time, questions surrounding this issue have only been examined by means of written material, observed over long periods of time. Only in the last few decades has the actual process of change in spoken every-day language come into focus. To William Labov we owe the helpful method of distinguishing between apparent-time and real-time analysis of language change (see Labov 1994, cf. Bailey et al. 1991, Haas 1999). With the following two examples, I will show how the language biographies of individual speakers can be used for systematic observation of language changes. As a fundamental means of eliciting this useful material, the re-recording of speakers enframed in lifetime-studies will be described. 


\section{Two case studies: Language biographies}

\subsection{Language maintenance and dialectal change}

First I would like to introduce Vreni. She lives in "America's Little Switzerland" in southern Wisconsin. Immigrating from Switzerland to Wisconsin as a toddler, she married there in the late 1920s and taught her husband - a Swiss - his first bits of English. The couple's language was Swiss German, but with their children they spoke only English. (The daughter confided that they, as children, experienced their parents' Swiss German as a kind of secret language in which they were not supposed to take part.)

The following excerpts of recordings taken in 1968 and 2001 present, as examples of the comparative linguistic material, two Wenker sentences and a narrative on the slaughtering of pigs.

\section{Example 1: Wenker sentences 4 and 5}

$1968 \mathrm{~L}=$ Interview: Brian Lewis, then grad. student in Madison, WI $\mathrm{G}=$ Speaker VG, female, G., Dane County, WI

L: (...) der gute alte Mann ist mit dem Pferde durchs Eis gebrochen G de alte

L: $\quad$ und in das kalte

G: Mann isch mit dem äh Rosse durs Iesch durchebroche

L: Wasser gefallen er ist vor vier oder

$\mathrm{G}$ un in das chalt Wasser kchfalle

L: sechs Wochen gestorben

G: er isch äh vier oder sechs Woche zrück gschtoorwe

$2001 \mathrm{~W}=$ Interview: Peter Wagener

$\mathrm{G}=$ Speaker VG, female, G., Dane County, WI

$\mathrm{W}:(\ldots)$ the good old man has broken through the ice with his horse

$\mathrm{G}$ : de alt

W:

$\mathrm{G}: \mathrm{Ma} *$ isch durche Ies durchebroche mit $\mathrm{m} \mathrm{Roß}$

W: water

$\mathrm{mhm} *$ he died four or six

G: and isch in des chalte Wasser rinnekiet

W: weeks ago

$\mathrm{G}$ : oh er isch drieä * drie oddr vier Woche zrück gschtoorba 


\section{Example 2: Slaughtering of pigs}

$1968 \mathrm{G}=$ Speaker VG, female, G., Dane County, WI

G: $(\ldots)$ äh $*$ wann ma hett weller ne Schwien metzker $* 2 *$ hoi- * heit sies

G: mittr er Nacht so vor (??)schlache ${ }^{*}$ heits kstoche mitm Messer * und

G: danach hett ma dann müesse ${ }^{*}$ Wassr ${ }^{*}$ kchoche bis $\mathrm{s}$ kchochend isch un

G: hetts Messer (...)

G: un da ${ }^{*}$ Würscht ${ }^{*}$ hett ma au a mache loe ${ }^{*}$ hett ma upr cha in Huus un

G: hett me mache lo * und hett sa ${ }^{*}$ ähm ${ }^{*}$ zimmerröcht hett ma au sauzi

G: kmacht ${ }^{*}$ und die andere hett ma in Steihawwe tuen und hett Schmutz heiß

G: kmacht un drüberglaat oddr de Gläseren steri- sterilisiert

$2001 \mathrm{~W}=$ Interview: Peter Wagener

G = Speaker VG, female, G., Dane County, WI

$\mathrm{T}=$ Daughter von VG

G: $(\ldots)$ oh Schwei- (LAUGHING) das isch gruusig * by me ${ }^{*}$ for mi isch es

G: gruusig * $3 *$ jaha * mir hett im Wintr immer $*$ hett mir kmetzgert $*$ un

G: hett e Choa kmetzgert un des * e Sau * ähm mau- * e Choa dät se schiässe

G: un des Sau well * e Sau channt die au schiässe un danach dät se steche

G: se chann gue blüete *

$\mathrm{W}: \quad$ und was hat man dann gemacht?

G:

mit dem Fleisch?

$\mathrm{W}:$
$\mathrm{G}:$ ja $*$ mit hei da * Metzger ka eine wo mer do e Lüüt des goe ushelfe (...)

$\mathrm{W}$ : und was für Würscht?

G:

was für ne Gwürscht? Jaa * äh * just * ich chant *

W:

G: eifach a Wurscht * me hett nett verschiedene Würscht kho * ${ }^{*}$ nn

W: von dem Blut eine?

G:

$\mathrm{T}$ :

na-a-a Blotwürscht? Nä-ä-ä * no-o 


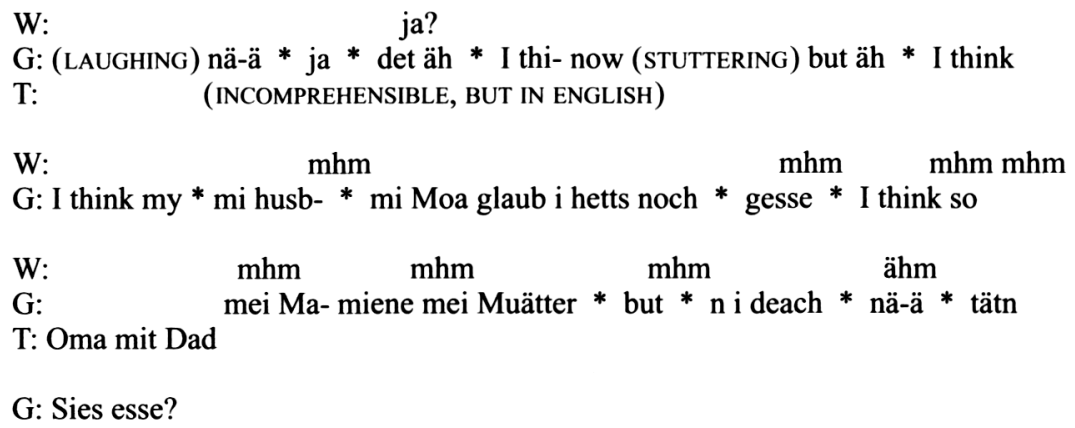

The code-switching in the end is effected by the interference of the daughter, who is present as well. Although she understands German well, the old communicative rule here upheld. Comparing the two recordings, it becomes very clear how few changes are indicated in Vreni's language. Her conditions of communication have stayed relatively stable. Today she resides in a nursing home, where she maintains everyday communication with a number of Swiss German speakers. Switching between German and English is still as normal for her as it has been from childhood on.

\subsection{Language loss}

My second example will illustrate the scope encompassed by the reality of language change: Anna from Manitowoc County at Lake Michigan.

We generally find a vast variety of motives to either keep speaking German or to give it up. This woman from R., Manitowoc County, told me that in her childhood the change from Low German to English took place when the children started school. This situation can often be observed, and usually leads to a complete abandonment of German by the children. This case, however, was an exception: while two aunts of the speaker, who were living with the family, were both deaf, they had learned to lip-read German - but not English. For that reason, the speaker kept her German - Low German in this case - along with English. It was a necessary means of comunication within the family as long as the aunts lived. The following excerpt of a transcript of this conversation displays an interesting switch from Low German to Standard German. This interview has been conducted primarily in English, except for the renewed questioning and translation of comparative texts (Wenker sentences etc.). It is a re-recording of a speaker Jürgen Eichhoff had previously interviewed in 1968, who has by now lost 
most of her abilities in Low German. (Here, the text about pig-slaughter has been cut after the sentences.)

\section{Example 1: Wenker sentences 4 and 5}

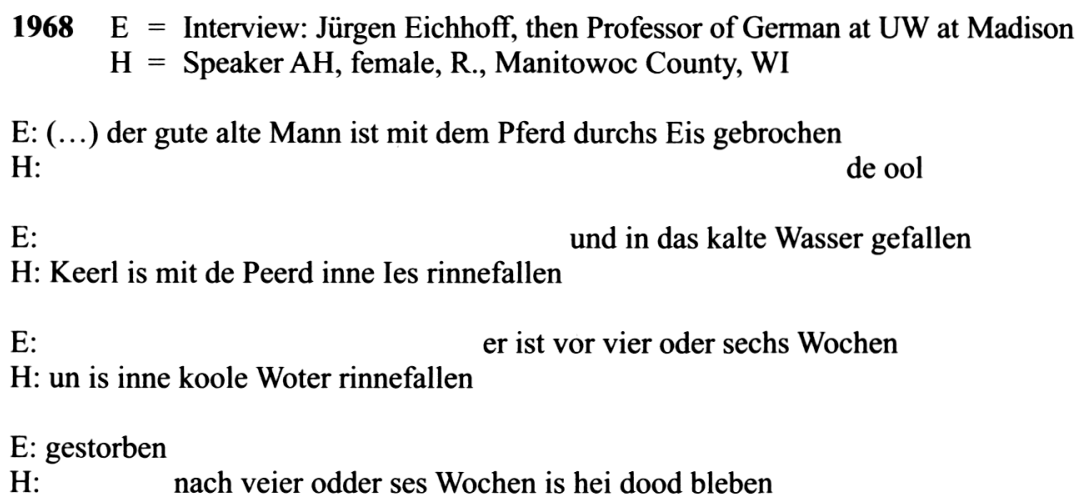

$2001 \mathrm{~W}=$ Interview: Peter Wagener

$\mathrm{H}=$ Speaker AH, female, R., Manitowoc County, WI

W: (...) der gute alte Mann ist mit dem Pferd durchs Eis gebrochen $\mathrm{H}:$ de $*$ de

$\mathrm{W}$ :

$\mathrm{H}$ : ool Keerl is $*$ in $* 2 *$ de lake fallen durch dat Ei- durch dat Ies mhm mit

W: dem Pferd

$\mathrm{H}$ : oh mit * mit de * Feerd * horses *2* mit de *5* I don't know

W:

$\mathrm{H}$ : what that will be in High German and Ge- and Plattdütsch either * mit de

W: mh Feerd or Peerd?

$\mathrm{H}: \mathrm{f}-{ }^{*} \mathrm{f}-\mathrm{Feerd}$ that would be the same thing ja I think

W: would you say Feerd or Peerd? is mit dem Pferd $* 2 *$ er ist H: so that's what I'd say Feerd ja

W: durchs Eis gebrochen $\mathrm{mhm} \quad \mathrm{mhm}$ und $\mathrm{H}$ is in de Ies falle is dörch de Ies falle

W: ins kalte Wasser gefallen und ins kalte Wasser gefallen * and $\mathrm{H}: \quad$ is what?

W: fallen into the cold water $\mathrm{H}$ :

un is äh un is * in de äh kool woter falln $\mathrm{mhm}$ 
W: er ist vor vier oder sechs Wochen gestorben

$\mathrm{H}$ :

he died about $*$ die $\mathrm{I}^{*}$ hei

W:

$\mathrm{H}$ : is dood bleewe onjefähr veier odder sechs Wochen vorher $\mathrm{mhmmhm}$

\section{Example 2: Wenker sentence 16}

$1968 \mathrm{E}=$ Interview: Jürgen Eichhoff

$\mathrm{H}=$ Speaker AH, female, R., Manitowoc County, WI

E: Du bist noch nicht groß genug, (...)

$\mathrm{H}$

du bist no nich groot nouch (...)

$2001 \mathrm{~W}=$ Interview: Peter Wagener

$\mathrm{H}=$ Speaker AH, female, R., Manitowoc County, WI

W: Du bist noch nicht groß genug, (...)

$\mathrm{H}$ :

du bist no nich groot $*$ enough $* 3 *$

W:

$\mathrm{H}: \mathrm{du} *$ du bist no nicht groß enough * ja du bist no nicht groß enough

\section{Example 3: Slaughtering of pigs}

$1968 \mathrm{H}=$ Speaker AH, female, R., Manitowoc County, WI

H: (...) denn wenn de Dach kome dee * denn müsste sei de Schwien rutegriepe $\mathrm{H}:{ }^{*}$ un * un un * denn müsste er mit de Äxt vör de Kopp schloan * denn $\mathrm{H}$ : hewwest de Butchermetze nohme un hewwet se inne Genick rinnestoke ${ }^{*}$ dat H: Blaut rutelope kill * un dat Blaut hewwet se bruukt tom Blautwust maken

$2001 \mathrm{H}=$ Speaker AH, female, R., Manitowoc County, WI

$\mathrm{H}:(\ldots)$ se se * bri bringe de Schwien * rute * un denn äh stäke sei s inne $\mathrm{H}: *$ in de neck $* 2 *$ in dat throat $*$ un denn ${ }^{*} 3 *$ mutt dat Blaut rutekomme * H: un denn hänge de Schwien up * un denn cut ${ }^{*}$ äh cut de $*$ cut de Schwien $\mathrm{H}$ : open in de front * and and and * see I get myself mixed up * un denn $\mathrm{H}$ : nehme se alle de insides rute ${ }^{*}$ un denn nehme se de insides * odder * se H: sei cleane de all * inside out * und denn * äh * schaffe se dat meat all $\mathrm{H}: \mathrm{ab} *$ und denn make dei * Wust out of dat 
To explicate the above situation more exactly: the behavior of the speaker in 2001 is determined by a great insecurity, and therefore contains several hesitations and interruptions in the translation of the sentences. The question now begged by the linguist is, of course, as to what happened in the meantime: how did the change, in the form of a partial loss of language competence, come to pass?

Researchers in the field of language change think they know how the reduction of language competence is effected. The loss is believed to be stronger in the more open levels of language analysis (such as the lexic) and much weaker in the more closed ones, such as phonetics/phonology. The presented excerpt displays the lexical gaps. Thus, at first sight it can be confirmed that there are more changes in these areas, and less among the phonological characters or even the suprasegmental characters of regional language.

\section{Analyzing real time change: The method of re-recording}

Still there remains a question: What is the motivation for, and relevance of, these renewed recordings? What do they forecast for research in language change?

It is helpful to examine dialectal and regional spoken varieties of Germanspeaking migrants - their language biographies, the changes in language use, and substance and system in an English-speaking environment. The material for this analysis is founded on a very effective methodical access of comparative analysis of historical and contemporary sound recordings. That means that the data the analysis is based on has been gathered by revisiting speakers interviewed in earlier sound recording-campaigns (cf. Wagener 1997, 1999, 2002).

With these methods, we are pursuing the aim of examining selected phenomena of language change in different varieties of spoken German in real time. Subject to this research are changes in the speech of the individual, as well as phenomena of social language change within the language communities, within a time frame of up to 53 years. The basis of the data collection are sound recordings of German-speaking immigrants in Wisconsin from the 1940 s and the 1960s. For comparison, sound recordings of the main German basic dialects, as well as sound recordings of dialect speakers from formerly German areas in Eastern Europe ("Flüchtlinge"), are used. These recordings are archived in the Archives of Spoken German, part of the Institute for German Language in Mannheim/Germany (see Knetschke and Sperlbaum 
1983, Haas and Wagener 1992; online www.ids-mannheim.de/DSAv). In the forefront of the analysis is the verification of recent hypotheses of research in language change. For example, it is postulated that disappearing varieties of German show a loss of lexical options, a simplified grammatical structure, and disorderly variation before their disappearance.

Very little is actually known about the concrete processes of language change, conversion, and loss. The most common pattern of loss of German in north America is the conversion or shift from generation to generation. This can be verified especially in the present. Indicative of this trend is the example of Hans from Ansbach/Bavaria, a brewer, who came to Wisconsin in the early 1970s. Hans is bilingual: he speaks German with his wife, but otherwise communicates primarily in English. Of his children, the son is bilingual as well, while the daughter is exclusively monolingual. Their children, in turn, are monolingual even in competence. Examples from the present like this one are commonplace; particularly amongst imigrants of the 1960s and '70s placed in university and corporate environments.

Language competency is usually coupled with a corresponding change of citizenship over generations:

- German and English, German passport, first generation

- Frequently both languages and citizenships, second generation

- English, American citizenship, third generation.

This model has consistently been used over the years and observes that the first generation was still completely German-speaking, while bilinguality usually marked the second generation, and the actual switch of languages occured in the third generation.

We know far less about the change and, when applicable, the loss of a language during the lifetime of one individual speaker. The dilemma in tracking this change is that there is no universal procedure for doing so, and at best, only isolated features are measured. There seems, however, a solution at hand, through the combination of single values. For all features included in the survey, I can determine a coefficient (of measure) which is modified only very slightly by the variation of single features. Tests with data of interview sequences confirm this. Thus my survey on individual language change is based not on the analysis of developments of isolated features, but on the comparison of indices representing the dialect level and the nonstandard level of different speech samples of single speakers, and rendering them commensurate (for more detailed information on the measuring procedure and more examples see Wagener 1997, 1999, 2002). 


\section{Results in figures}

Applied to comparisons of various time periods, represented by tape recordings in 1968 and 2001, indices which have been determined for all nonstandard features can be related to each other. The indices of all features (here taken from Winteler 1876, Streiff 1915 and Lewis 1968) are marked as the most salient features for Schwyzertütsch by these authors. They are compared in figure 1.

The indices of all features of the Low German speaker of Manitowoc (here taken from Lauf 1988, Niebaum 1977, Seymour 1970, 1978a, 1978b, Stellmacher 1981) are salient features as well. They are compared in figure 2.

The data here graphically presented may give an indication of what kind of results may be drawn from real time analyses like these, and in which way the tendencies recorded on the tapes (and in small excerpts given in the transcripts) can be verified. Summarizing the results, we can clearly identify discrepancies in language loss, in this example between the speaker of Schwyzertütsch, who maintains her dialectal competence over her lifetime, and the speaker of Low German, who largely lost her competence after three decades.

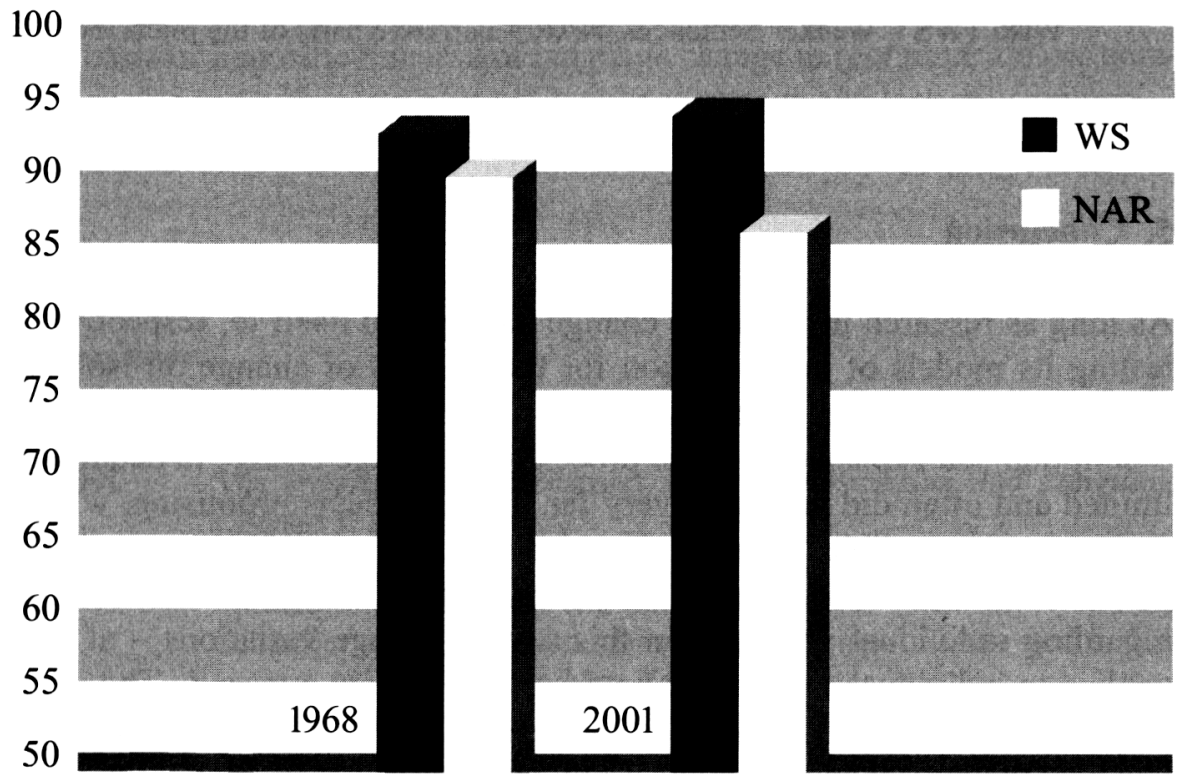

Fig. 1. Vreni 1968 and 2001

Dialect level: Percentage of all features - Place: G., Dane County, Wisc. (WS $=$ Wenker Sentences, NAR $=$ narrative parts of the interview) 


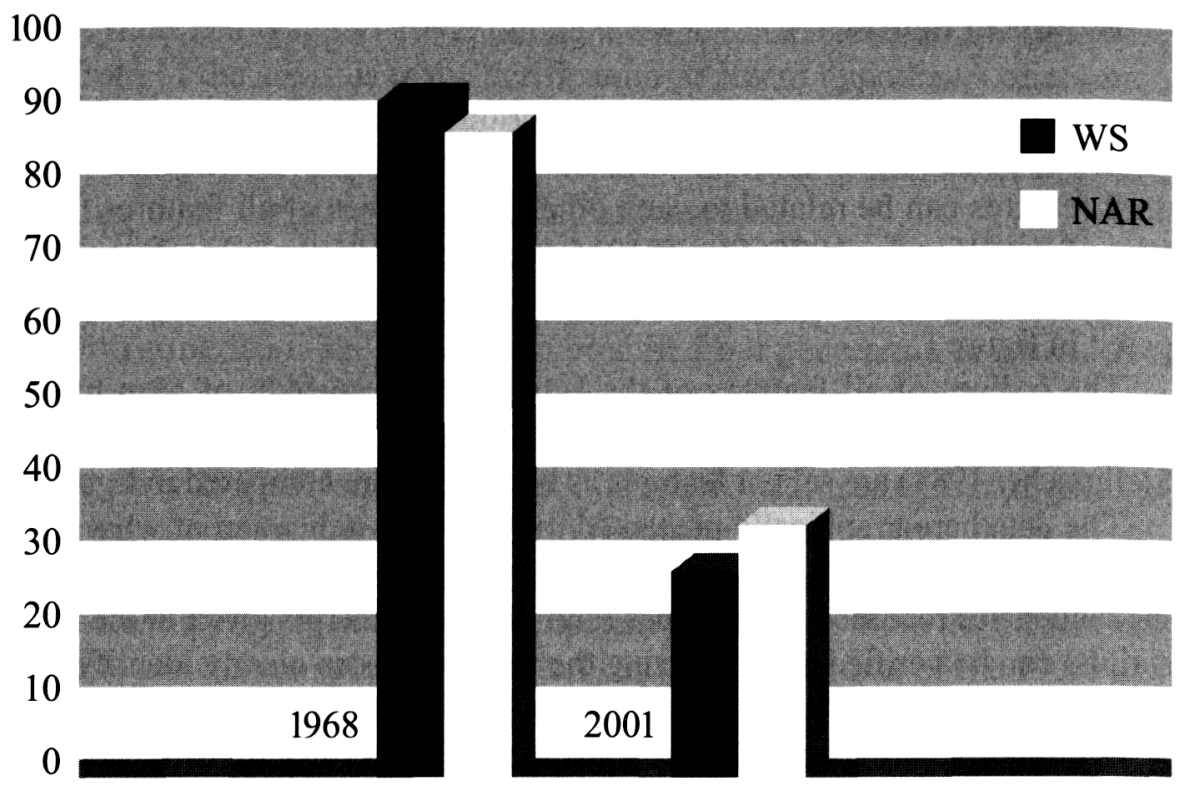

Fig. 2. Anna 1968 and 2001

Dialect level: Percentage of all features - Place: R., Manitowoc County, Wisc. $($ WS $=$ Wenker Sentences, NAR $=$ narrative parts of the interview $)$

\section{Conclusion}

As long as research in language change has limited itself to, respectively, testing its models of interpretation for the process of change on isolated phenomena or on small amounts of material, the potentiality of a cohesive description and explanation of the process of language change in detail was limited and often did not reach very far. Thus, it seems promising, within the scope of extendible "speaker's linguistics" (cf. Macha 1991), exemplified by case studies, to concentrate on explicitly observable processes of change regarding individual speakers. In this way, language variations - at first applied to individual cases - can be described in statu nascendi. The more reconstrucions of individual cases can be related to each other - based on identical theoretical and methodical prerequisites of observation - the more clearly will regularities show, and thus mechanisms be reconstructed. Possibilities to empirically reconsider and support theoretical assumptions will then result. These possibilities result from an effort towards further findings 
on the conditions, mechanisms and results of language change. This effort is one of the central concerns of linguistics, and here linguists' attention has, as a rule, been directed primarily toward longer periods of time. Also, nolens volens written sources have been used, often without regard to their reliability. Using these sources, linguists could describe the results of language change, but the process itself has often been neglected. For that reason, research is increasingly trying to access spoken material for reference. In accordance with the premise, that the development of a language is made accessible through the help of several synchronic cuts, there have arisen different ways to register the language as manifested in the past, in order to compare it to the current state of development. Such relativist systems are recruited from descriptions of medieval realisations of languages (such as Old Saxon or MHG). Within German dialectology, the tertium comparationis has also been taken from i.e. Georg Wenker's early elicitations to the "Deutscher Sprachatlas" for an allotment of time in the late $19^{\text {th }}$ century. Another supportive technique often used in recent linguistic studies is the simulation of time periods. This is predicated on the assumption that language variation can serve as a model for different phases of a process of language change.

I believe that we need no longer depend on such methods. If we systematically pursue the method of re-recording to obtain material from real situations as a basis of linguistic research of language change in real time, a more comprehensive and accurate picture of language change and loss may emerge.

\section{References}

Bailey, Guy, Tom Wikle, Jan Tillery and Lori Sand

1991 The apparent Time Construct. Language Variation and Language Change 3: 241-264.

Haas, Walter

1999 Sprachwandel in apparent time und in real time. In: Wolfgang Schindler and Jürgen Untermann (eds.), Grippe, Kamm und Eulenspiegel, 125-144. Berlin/New York: de Gruyter.

Haas, Walter and Peter Wagener (eds.)

1992 Gesamtkatalog der Tonaufnahmen des deutschen Spracharchivs, vol. 2. Tübingen: Niemeyer.

Knetschke, Edeltraud and Margret Sperlbaum

1983 Das Deutsche Spracharchiv im Institut für deutsche Sprache. Mannheim. 
Labov, William

1994 Principles of Linguistic Change. Oxford: Blackwell.

Lewis, Brian A.

1968 The Phonology of the Glarus Dialect in Green County. Ph.D. dissertation, University of Wisconsin at Madison.

Lauf, Raphaela

1988 Veränderungen im Langvokalsystem nordniedersächsischer Ortsdialekte zwischen 1879 und 1986. Jahrbuch des Vereins für niederdeutsche Sprachforschung 111: 103-114.

Macha, Jürgen

1991 Der flexible Sprecher. Untersuchungen zu Sprache und Sprachbewußtsein rheinischer Handwerksmeister. Köln: Böhlau.

Niebaum, Hermann

1977 Westfälisch. Düsseldorf: Schwann.

Seymour, Richard K.

1970 Linguistic Change: Examples from the Westfalian Dialect of Nienberge. WORD 26/1: 32-46.

1978a Linguistic Change: Examples from the Verb System of the Westfalian Dialect of Nienberge (near Münster). In: M. A. Tazayery et al. (eds.), Festschrift für A. A. Hill, 237-248. Lisse.

1978b Linguistic Change in the Westfalian Dialect of Nienberge: Preliminary Investigation Based on Comparison of Two Versions of a Text. In: Stephen J. Kaplowitt (ed.), Germanic Studies in Honor of Springer, 305-328. Pittsburgh.

Stellmacher, Dieter

$1981 \quad$ Niedersächsisch. Düsseldorf: Schwann.

Streiff, Catharina

1915 Die Laute der Glarner Mundarten. Frauenfeld.

Wagener, Peter

1997 Nach 40 Jahren: Zu individuellen Veränderungen der gesprochenen Sprache. In: Gerhard Stickel (ed.), Varietäten des Deutsch: Regionalund Umgangssprachen, 291-307. Berlin.

1999 Niederdeutsch im Wandel. Eine Panelstudie zum Wandel des gesprochenen Deutsch in realer Zeit. Jahrbuch des Vereins für niederdeutsche Sprachforschung 122: 45-66.

2002 German Dialects in Real-Time Change. Journal of Germanic Linguistics 14/3: 271-285.

Winteler, Jost

1876 Die Kerenzer Mundart des Kantons Glarus in ihren Grundzügen dargestellt. Leipzig/Heidelberg. 